\title{
Maximum growth and survival of estrogen receptor-alpha positive breast cancer cells requires the $\operatorname{Sin} 3 \mathrm{~A}$ transcriptional repressor
}

\author{
Stephanie J Ellison-Zelski, Elaine T Alarid ${ }^{*}$
}

\begin{abstract}
Background: $\operatorname{Sin} 3 \mathrm{~A}$ is an evolutionarily conserved transcriptional repressor which regulates gene expression as part of the multi-protein $\operatorname{Sin} 3$ repressive complex. It functions as a scaffold upon which proteins with enzymatic activity dock, including chromatin modifying histone deacetylases. Although regulation of transcription by $\operatorname{Sin} 3 \mathrm{~A}$ has been studied in detail, little is understood about the function of $\operatorname{Sin} 3 \mathrm{~A}$ in cancer cells. We previously showed that $\operatorname{Sin} 3 \mathrm{~A}$ is expressed in breast cancer cells and is a repressor of estrogen receptor-alpha (ER $\alpha, E S R 1)$ gene expression. Here, we expand our previous studies to elucidate the function of $\operatorname{Sin} 3 \mathrm{~A}$ in the control of gene expression and growth of breast cancer cells.

Results: Analysis of gene expression following knockdown of Sin3A revealed changes in both basal and regulated gene transcription. Genes of known importance in breast cancer and estrogen signaling, including ERBB2, PGR, MYC, CLU, and NCOA2, were among those identified as Sin3A-responsive. The mechanism of $\operatorname{Sin} 3 \mathrm{~A}$ action varied among genes and was found to be mediated through both HDAC1/2 -dependent and -independent activities. Loss of Sin3A inhibited breast cancer cell growth by increasing apoptosis without affecting cell cycle progression. Analysis of both $E R \alpha$-positive and ER $\alpha$-negative cell lines revealed that the effects of $\operatorname{Sin} 3 \mathrm{~A}$ on growth were celltype specific, as $\operatorname{Sin} 3 \mathrm{~A}$ expression promoted maximum growth of only the ERo-positive cells, and, notably, Sin3A protein itself was increased by estrogen. Further gene expression experiments revealed that $\operatorname{Sin} 3 A$ repressed expression of key apoptotic genes, including TRAIL, TRAILR1, CASP10, and APAF1, in ERo-positive, but not ER $\alpha$ negative, cell lines, which could provide a mechanistic explanation for cell-type differences in growth.

Conclusions: This study identifies Sin3A as a regulator of gene expression, survival, and growth in ERo-positive breast cancer cells. Sin3A regulates the transcription of genes involved in breast cancer and apoptosis and acts through multiple mechanisms not limited to histone deacetylase function. These findings reveal previously undescribed functions of $\operatorname{Sin} 3 \mathrm{~A}$ in breast cancer and provide evidence for an important role of this transcriptional repressor in ERa-positive tumor cell growth.
\end{abstract}

\section{Background}

Appropriate regulation of genes is important in maintaining normal cell growth, and disruption of gene regulation is associated with human cancer. Changes in gene expression can distinguish types of breast tumors and predict response to therapies [1-3]. Tremendous effort, therefore, has been devoted to dissecting pathways that regulate transcription. For example, understanding the mechanisms of gene activation by estrogen receptor-

\footnotetext{
*Correspondence: alarid@oncology.wisc.edu

Department of Oncology, University of Wisconsin-Madison, Madison, Wisconsin 53706, USA
}

alpha $(E R \alpha)$ was foundational in the development of hormonal therapy [4]. Interestingly, microarray analyses on estrogen-treated breast cancer cells show that the number of repressed genes is greater than or near the number of activated genes [5-8]. Although these experiments show that estrogen-mediated repression of genes is clearly biologically important, the mechanisms responsible for repression are not fully understood. We previously showed that the Sin3A transcriptional repressor protein is a regulator of estrogen-induced repression of the ER $\alpha$ gene, ESR1, in breast cancer cells [9]. Furthermore, it was found that $\operatorname{Sin} 3 \mathrm{~A}$ and ER $\alpha$ exist in

\section{Biomed Central}


an endogenous estrogen-responsive complex. These data suggested that Sin3A may play a broader role in ER $\alpha$ positive breast cancer cells.

The role of Sin3A in breast cancer is virtually unexplored, but studies suggest that Sin3A is important in normal growth and may be a player in other neoplastic model systems. Homozygous deletion of Sin3A in mice is embryonic lethal, demonstrating that Sin3A serves essential developmental functions $[10,11]$. Studies using conditional Sin3A knockout in mouse embryonic fibroblasts (MEFs) find that Sin3A deletion leads to decreased proliferation and increased apoptosis of cells $[10,11]$. In cancer models, Sin3A function is less clear. Lymphoma and sarcoma cell lines derived from primary tumors arising in a $\mathrm{p} 53^{-1-}$ background exhibit proliferative arrest and increased apoptosis upon Cre-mediated deletion of Sin3A, suggesting that Sin3A has oncogenic functions [11]. However, another report suggests that Sin3A functions as a tumor suppressor in non-small cell lung cancer (NSCLC), as down-regulation of Sin3A mRNA occurs in several cases of NSCLC [12]. These few reports with disparate findings highlight a fundamental lack of understanding of the role of $\operatorname{Sin} 3 \mathrm{~A}$ in growth and cancer.

At the molecular level, Sin3A functions as the scaffolding component of the multi-protein Sin 3 repressor complex that mediates transcriptional repression of several genes. The Sin 3 complex was identified in yeast but is conserved in species through mammals $[13,14]$. The characteristic catalytic activity associated with $\operatorname{Sin} 3 \mathrm{~A}$ is histone deacetylation via its interactions with HDAC1/2 $[15,16]$. Additional components of the complex consist of SAP18/30, which stabilize the Sin3A-HDAC interaction, and RbAp46/48, which anchor the Sin 3 complex on nucleosomes [15-17]. Sin3A does not possess intrinsic DNA-binding activity, so it must be targeted via interaction with other DNA-bound factors. Interactions for numerous DNA-binding factors and Sin3A have been identified, including Mad, p53, MeCP2, NRSF, CTCF, and ER $\alpha$ as examples [9,18-22]. Sin3A can also interact with other enzymatic proteins, including those capable of histone methylation, DNA methylation, chromatin remodeling, and $\mathrm{N}$-acetylglucoseamine transferase activity [20,23-28].

In this report, we expand our previous findings and identify the function of Sin3A in gene expression, survival, and growth of breast cancer cells. Gene expression analysis identified a specific subset of Sin3A-responsive genes that were regulated by both HDAC1/2-dependent and -independent mechanisms. Importantly, decreased Sin3A expression led to an increase in apoptosis and increased expression of several apoptotic genes, which translated into attenuation of cell growth of ER $\alpha$-positive and not ER $\alpha$-negative breast cancer cells. This study identifies Sin3A as an essential regulator of growth and survival of ER $\alpha$-positive breast cancer cells, which may have important translational implications for breast cancer patients.

\section{Results}

Sin3A regulates basal expression and estrogen-induced responses of specific genes in breast cancer cells

Sin3A is a conserved multifunctional repressor protein present in organisms from yeast to mammals that functions by regulating gene transcription [17]. Our lab previously showed that Sin3A regulated the estrogeninduced repression of the ER $\alpha$ gene, ESR1, in the MCF7 breast cancer cell line [9]. To identify other genes regulated by Sin3A, MCF7 cells were transfected with a scrambled (scr.) negative control or Sin3A siRNA followed by treatment with vehicle ethanol $(\mathrm{EtOH})$ or 10 nM 17- $\beta$-estradiol (estrogen, E2). Knockdown of Sin3A protein and mRNA by Sin3A siRNA were validated by western blot and quantitative reverse transcriptase realtime PCR (qRT-PCR), respectively (Figure 1A and 1B; the band for the Sin3A protein at the molecular weight of $145 \mathrm{kDa}$ is marked with an asterisk). As an initial approach to identify Sin3A-regulated genes, a preliminary screen was performed of 84 genes that were identified based on their importance to breast cancer and estrogen signaling using a SABiosciences $\mathrm{RT}^{2}$ Profiler PCR array. From this screen, 26 genes, including those that were and those that were not changed by Sin3A knockdown, were selected for validation by qRT-PCR in three independent experiments.

Expression data were analyzed for regulation by Sin3A, resulting in two groups of genes shown in Table 1: Sin3A responsive and Sin3A non-responsive. Sin3A responsive genes were those whose basal level (shown in bold) or estrogen response (shown in bold italic) were significantly $(p<0.05)$ changed in the presence of Sin3A siRNA compared to control scrambled transfected cells. For basal gene regulation by Sin3A, statistical analysis identified a 1.75 fold change as a cutoff for significant regulation. This resulted in eight Sin3A-responsive genes, all of which showed an increase in basal expression in the presence of Sin3A siRNA, in agreement with its role as a repressor of transcription. Graphs of qRT-PCR data from the three genes whose basal levels increased greatest with $\operatorname{Sin} 3 \mathrm{~A}$ knockdown, $C 3, C L U$, and $E R B B 2$, are shown in Figure $1 C$, along with an example of a gene whose levels did not change, TOP $2 A$. For identifying genes whose estrogen responses were altered by Sin3A knockdown, any significant change in the response was allowed, resulting in four total genes. Sin3A siRNA prevented significant estrogen-induced repression of both ESR 1 and NCOA2; ESR1 regulation by Sin3A had been shown 

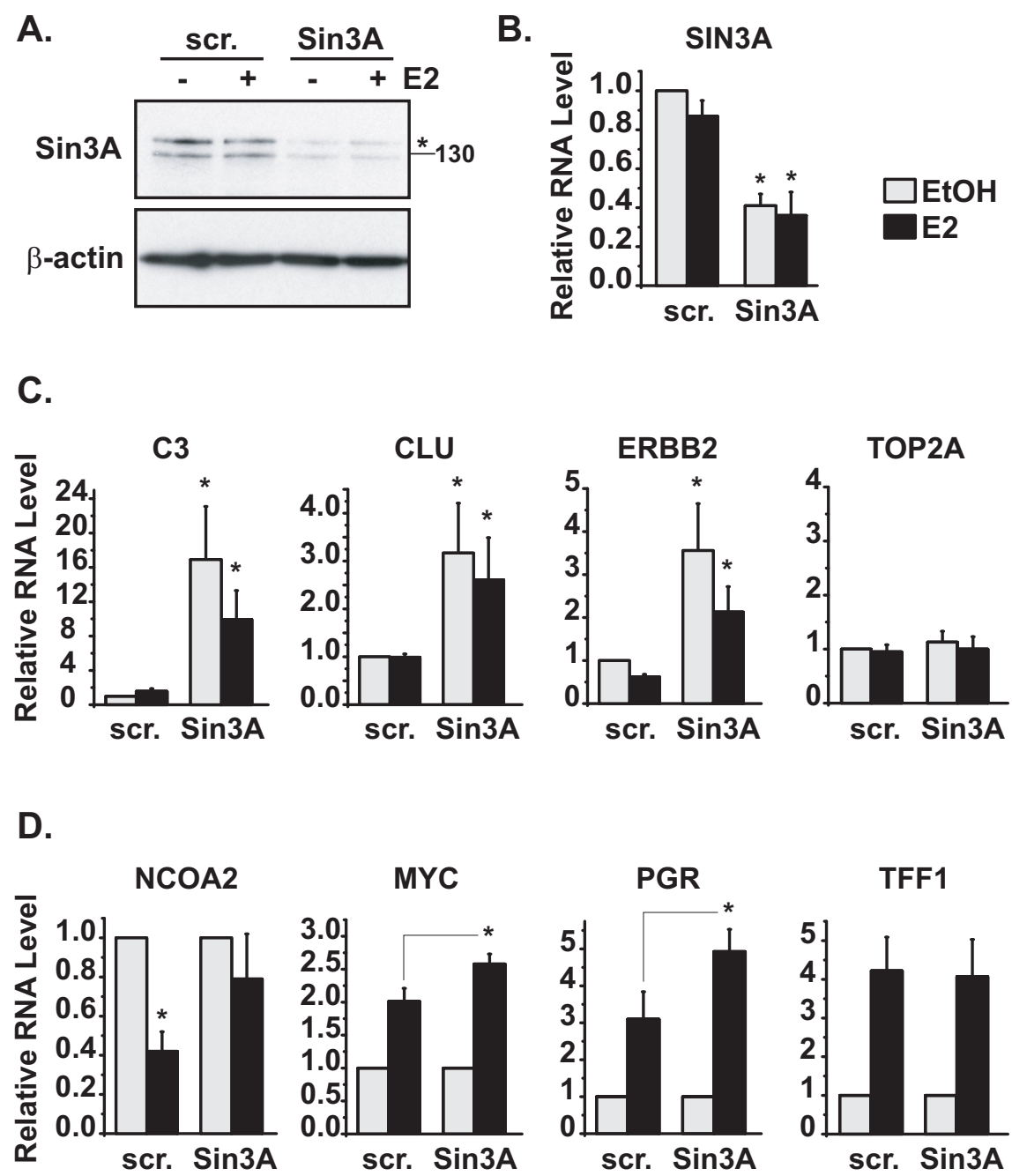

Figure $1 \operatorname{Sin} 3 \mathrm{~A}$ controls basal levels and estrogen-induced responses of genes in breast cancer cells. MCF7 cells were transfected with scrambled (scr.) negative control or Sin3A siRNA, followed by treatment with vehicle control ethanol (EtOH) or $10 \mathrm{nM} 17-\beta$-estradiol (estrogen, E2) for four hours. (A) Knockdown of Sin3A protein was confirmed by western blot analysis. The band specific for $\operatorname{Sin} 3 \mathrm{~A}$, which is a $145 \mathrm{kDa}$ protein, is marked with an asterisk. The blot was reprobed with $\beta$-actin for the loading control. (B) Knockdown of SIN3A mRNA was also verified using quantitative reverse transcriptase real-time PCR (qRT-PCR), with ribosomal protein P0 serving as the housekeeping normalization gene. RNA levels were calculated relative to the scrambled ethanol sample. Data are from four independent experiments with error bars showing the standard error of the mean. Student's $t$ tests were performed comparing corresponding scrambled and Sin3A siRNA samples, ${ }^{*} p<0.05$. (C) qRTPCR data, regulation of basal levels of genes, C3, CLU, ERBB2, and TOP2A. Experiments were performed and data calculated as above. (D) qRT-PCR data, regulation of estrogen responses of genes, NCOA2, MYC, PGR, and TFF1. Experiments were performed as above. RNA levels were calculated for each siRNA group relative to the corresponding ethanol-treated sample. Student's $t$ tests were performed comparing estrogen responses in the presence of scrambled versus Sin3A siRNA for MYC and $P G R$, and determining significant repression of NCOA2, ${ }^{*} p<0.05$.

previously by our lab [9]. The estrogen-induced activation of $M Y C$ and PGR were significantly increased in the presence of Sin3A siRNA, consistent with the loss of a transcriptional repressor. Graphs of qRT-PCR data from these genes are shown in Figure 1D, along with TFF1 whose estrogen response was not changed with Sin3A knockdown. The basal levels of the genes in Figure 1D did not change significantly (NCOA2, $1.34 \pm$ 0.13; MYC, $1.24 \pm 0.24 ;$ PGR, $0.88 \pm 0.17 ;$ TFF $1,1.47 \pm$
0.35 ), and data are graphed as fold changes to highlight the magnitude of the estrogen response. Genes on the right-hand side of Table 1, Sin3A non-responsive, were those that did not statistically change either at the basal level or in the magnitude of their estrogen-response with Sin3A siRNA. These results identify a specific subset of genes regulated by Sin3A in breast cancer cells and show that Sin3A mediates both basal and regulated gene expression. 
Table 1 Sin $3 A$ regulation of genes associated with breast cancer or estrogen receptor signaling

\begin{tabular}{cc}
\hline Sin3A Responsive & Sin3A Non-responsive \\
\hline C3 & CCND1 \\
CDH1 & CCNG2 \\
CDKN1A & HMGB1 \\
CLU & KRT18 \\
ERBB2 & KRT19 \\
GATA3 & MAP2K7 \\
MUC1 & NCOA3 \\
SERPINA3 & NME1 \\
ESR1* & PIN1 \\
MYC & SERPINB9 \\
NCOA2 & TFF1 \\
PGR & TGFA \\
& TOP2A \\
\end{tabular}

bold $=$ significant $(p<0.05)$ increase in basal level of gene by Sin 3A siRNA bold italic $=$ significant $(p<0.05)$ change in estrogen response of gene by Sin3A siRNA.

* $=$ previously identified [9].

\section{Effects of Sin3A on gene expression are mediated through HDAC1/2-dependent and-independent mechanisms}

The enzymatic function characteristically associated with Sin3A is histone deacetylation via its core interactions with HDAC1 and HDAC2 [16]. However, several studies have shown that this function can be expanded by adding alternative catalytic components onto the Sin3A platform [20,23-28]. To gain mechanistic insight into Sin3A target gene regulation, siRNAs directed against HDAC1 and HDAC2 were used to establish whether changes observed in gene expression in Figure $1 \mathrm{C}$ and 1D were mediated via Sin3A's associated core histone deacetylase activity. MCF7 cells were transfected with scrambled negative control, HDAC1, or HDAC2 siRNA, followed by treatment with vehicle ethanol or estrogen. Experiments also included a double HDAC1 and HDAC2 knockout since both are present in the Sin3A complex. Knockdown of HDAC1 and HDAC2 protein and mRNA levels were verified by western blot and qRT-PCR analysis (Figure 2A and 2B). Although modest regulation of the proteins by the opposite siRNA was observed, the qRT-PCR data showed specific regulation at the transcript level by respective HDAC siRNAs.

Genes from Figure 1 (C3, CLU, ERBB2, NCOA2, $M Y C$, and $P G R$ ) which were regulated by $\operatorname{Sin} 3 \mathrm{~A}$ were analyzed for changes in expression in the presence of decreased HDAC1 and HDAC2 levels. C3, whose basal levels increased in response to Sin3A siRNA (Figure $1 C$ ), also increased with the loss of HDAC1 or HDAC2 by siRNA (Figure $2 \mathrm{C}$ ). In contrast, the levels of $C L U$, whose basal levels also increased in response to $\operatorname{Sin} 3 \mathrm{~A}$
siRNA, were not increased by any of the HDAC siRNAs, even in the double HDAC1 and HDAC2 sample (Figure 2C). ERBB2 showed similar results to CLU (data not shown). For regulated responses, the estrogeninduced repression of NCOA2 was reversed when both HDAC1 and HDAC2 were decreased (Figure 2D), similar to the reversal of repression observed with $\mathrm{Sin} 3 \mathrm{~A}$ siRNA (Figure 1D). Conversely, none of the HDAC siRNAs significantly affected the level of estrogen-induced activation of the $M Y C$ gene (Figure 2D) or PGR (data not shown). In sum, the loss of HDAC1 and HDAC2 increases $C 3$ and $N C O A 2$, but not $C L U, E R B B 2, M Y C$, or PGR, providing evidence that $C 3$ and $N C O A 2$ are repressed in breast cancer cells by the HDAC $1 / 2$ components of the Sin3A repressive complex. These data establish that changes mediated by $\operatorname{Sin} 3 \mathrm{~A}$ in both basal and estrogen responses of genes involve $\mathrm{HDAC} 1 / 2$ dependent and -independent mechanisms and are gene specific.

\section{Loss of Sin3A promotes apoptosis of breast cancer cells but does not affect cell cycle progression}

Gene expression studies described above showed that loss of Sin3A affected a specific subset of genes involved in breast cancer by both increases in the basal level and modulation of estrogen responses. Furthermore, some mechanisms of regulation involved the HDAC $1 / 2$ activity of the core Sin3A complex (C3, NCOA2), while others involved alternative capabilities ( $C L U, M Y C)$. Together, this suggested that Sin3A was a master scaffolding protein whose broad effects on genes may translate into an effect on cell growth. Few studies have been conducted on the role of Sin3A in growth of mammalian cells, and these few reports have suggested conflicting roles for Sin3A in cancer $[11,12]$.

Flow cytometry analysis was performed on Sin3A knockdown cells to determine the role of Sin3A in cell cycle progression of breast cancer cells. MCF7 cells were transfected with scrambled or Sin3A siRNA and treated with or without estrogen for 72 or 96 hours. At 72 hours, there was no difference in the cell cycle distribution, determined by Hoescht dye intensity, of scrambled and Sin3A siRNA cells treated with vehicle ethanol (Figure 3A). Similarly, there was no difference in the cell cycle distribution of cells transfected with scrambled or Sin3A siRNA and treated with estrogen. As expected, estrogen treatment resulted in an increase in the percentage of cells in the $S / G 2 / M$ phases and a subsequent decrease in G0/G1 phases [29]. Similar results were found with the 96 hour samples, shown in the right panel of Figure $3 \mathrm{~A}$, indicating that $\mathrm{Sin} 3 \mathrm{~A}$ is not involved in cell cycle progression of MCF7 cells. Knockdown of Sin3A under these conditions was verified and is shown in Figure 4B. 


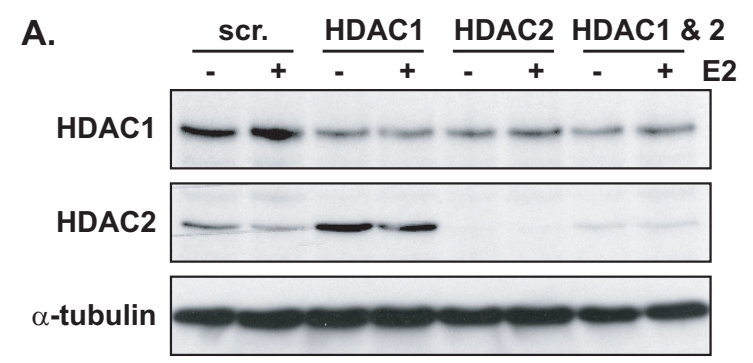

B.
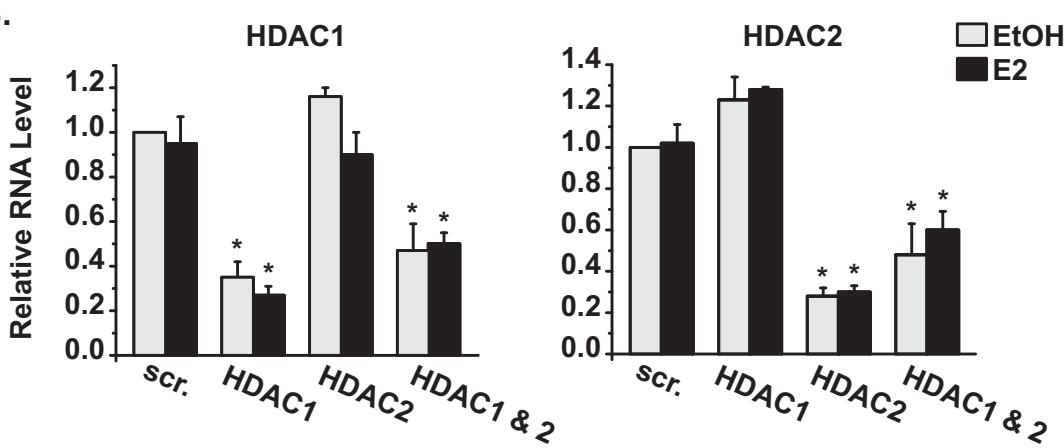

C.
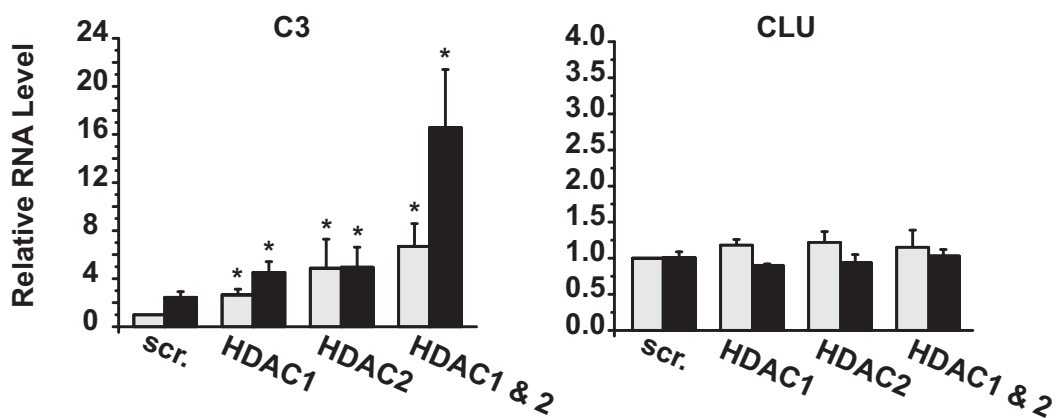

D.
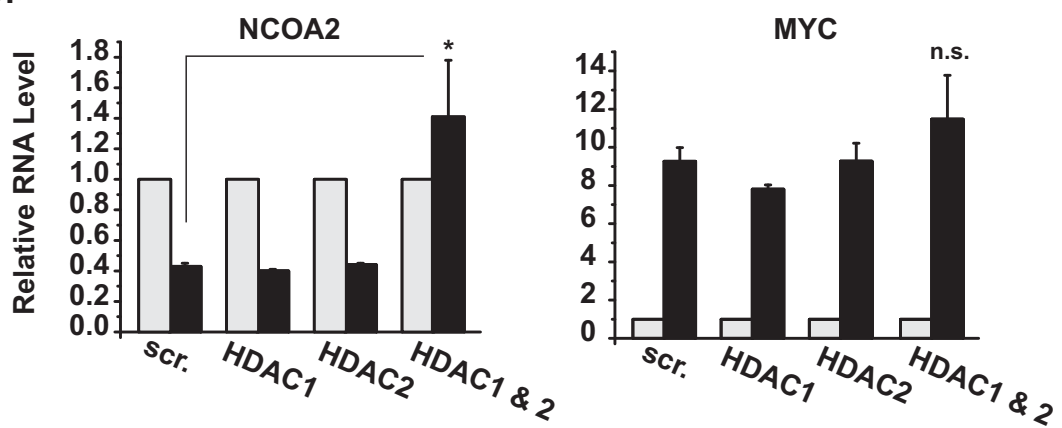

Figure 2 Changes in gene expression by Sin3A are mediated through HDAC1/2-dependent and -independent pathways. MCF7 cells were transfected with scrambled (scr.), HDAC1, HDAC2, or a combination of HDAC1 and HDAC2 siRNA, followed by treatment with ethanol $(\mathrm{EtOH})$ or $10 \mathrm{nM}$ estrogen (E2) for four hours. (A) Knockdown of HDAC1 and HDAC2 proteins was confirmed by western blot analysis, and the blot was reprobed with $\alpha$-tubulin for the loading control. (B) Knockdown of HDAC1 and HDAC2 mRNA was also verified using qRT-PCR, with ribosomal protein PO serving as the housekeeping normalization gene. RNA levels are calculated relative to the scrambled ethanol sample. Data are from three independent experiments with error bars showing the standard error of the mean. Student's $t$ tests were performed comparing corresponding scrambled and HDAC1 or HDAC2 siRNA samples, ${ }^{*} p<0.05$. (C) qRT-PCR data, regulation of basal levels of genes, C3 and CLU. Experiments were performed and data calculated as above. (D) qRT-PCR data, regulation of estrogen responses of genes, NCOA2 and MYC. Experiments were performed as above. RNA levels were calculated for each siRNA group relative to the corresponding ethanol-treated sample. Student's $t$ tests were performed comparing estrogen responses in the presence of scrambled versus HDAC siRNAs, ${ }^{*} p<0.05$. ns $=$ not significant. 


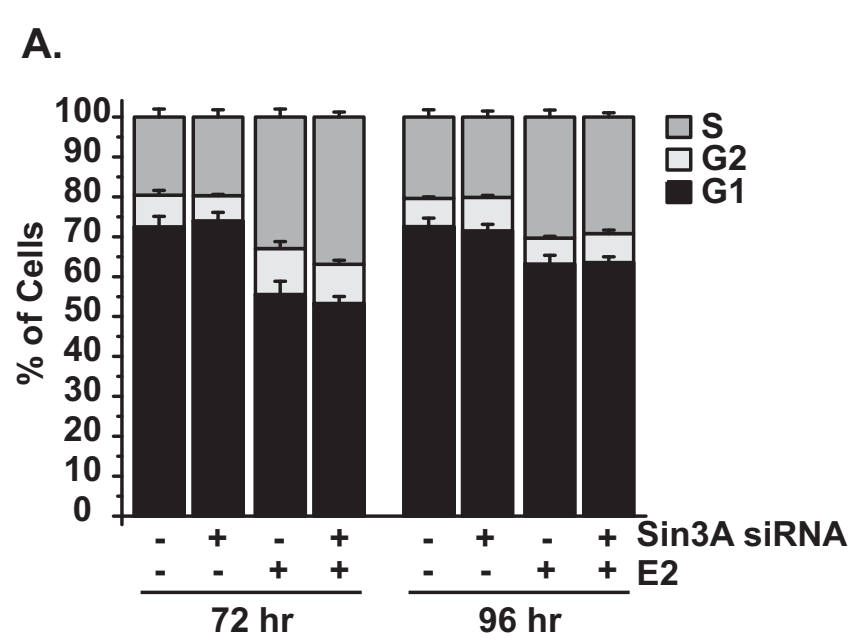

B.

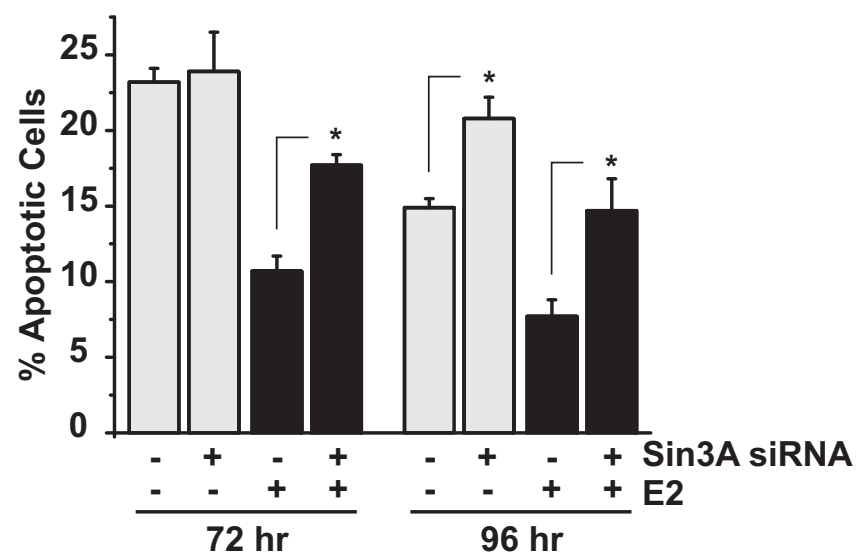

Figure 3 Loss of Sin3A increases apoptosis but does not affect the cell cycle of breast cancer cells. MCF7 cells were transfected with scrambled negative control or Sin3A siRNA and treated with vehicle ethanol or $10 \mathrm{nM}$ estrogen (E2) for 72 or 96 hours. Samples were analyzed simultaneously by flow cytometry for (A) cell cycle distribution and (B) annexin V, indicative of apoptotic cells. Data are from three independent experiments with error bars showing the standard error of the mean. To determine statistical significance of the findings in (B), student's $t$ tests were performed comparing corresponding scrambled and Sin3A siRNA samples, ${ }^{*} p<0.05$.

The samples described above were analyzed simultaneously for Annexin V staining to assess the level of cellular apoptosis. At the 72 hour time point, there was no difference in apoptosis of scrambled and Sin3A siRNA transfected cells treated with vehicle ethanol (Figure 3B). Estrogen treatment in control transfected cells decreased the level of apoptosis compared to ethanol (first bar versus third bar in Figure 3B). However, this level of apoptosis was significantly increased with loss of Sin3A (third bar versus fourth bar in Figure 3B). By 96 hours, there was a significant increase in apoptosis in Sin3A siRNA knockdown cells both in the presence and absence of estrogen. This identifies Sin3A as a prosurvival factor in MCF7 cells that protects against apoptosis.

\section{$\operatorname{Sin} 3 \mathrm{~A}$ is required for maximum growth of $E R \alpha$-positive} breast cancer cells

Cell growth assays were performed to determine if the observed increase in apoptosis by Sin3A knockdown was sufficient to attenuate growth of breast cancer cells. Since the increase in apoptosis at 96 hours occurred both in the presence and absence of estrogen (Figure $3 \mathrm{~B}$ ), the growth of ER $\alpha$-negative (MDA-MB-231 and Hs578T) as well as ER $\alpha$-positive (MCF7 and T47D) cell lines was analyzed. Cells were transfected with either the negative control scrambled or Sin3A siRNA, treated with vehicle ethanol or estrogen, and the number of live cells was counted every 24 hours by trypan blue exclusion (Figure 4). MCF7 cells transfected with the scrambled negative control grew steadily in the presence of estrogen, 

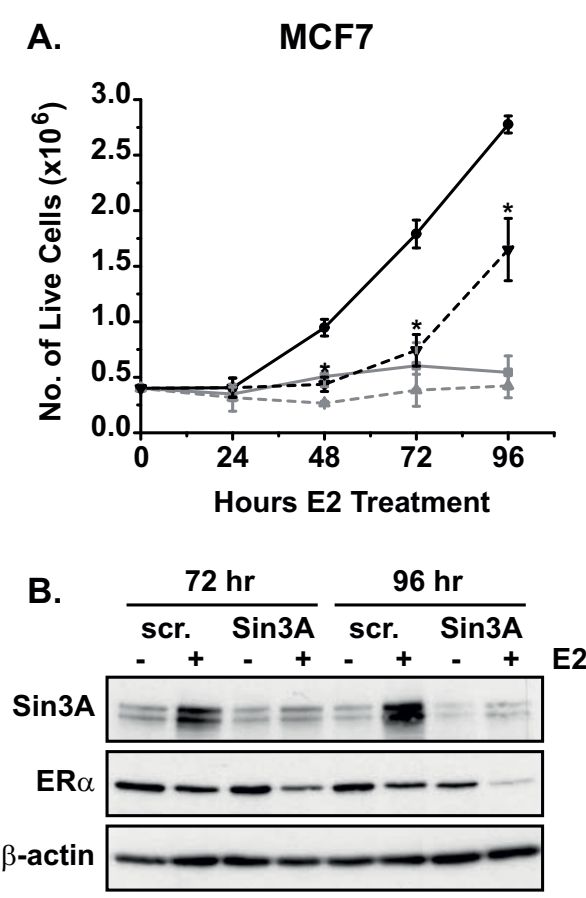

E.

MDA-MB-231
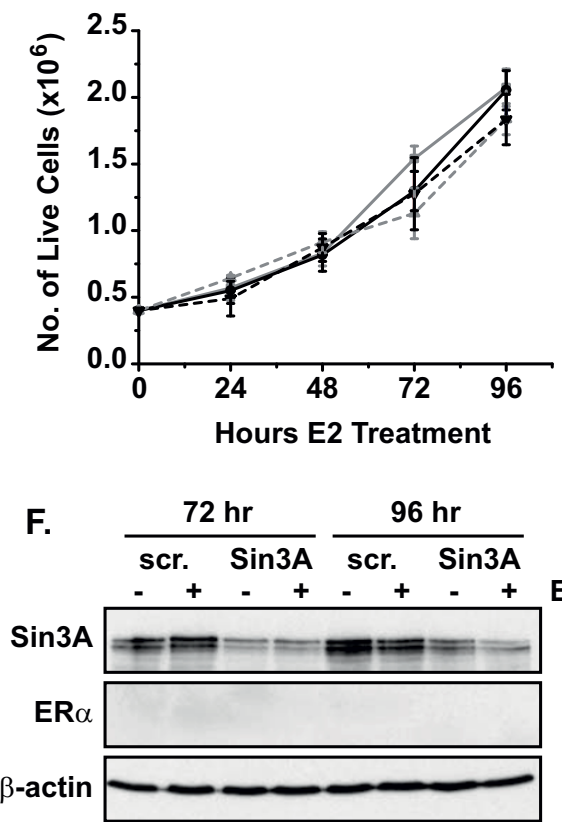

C.

T47D
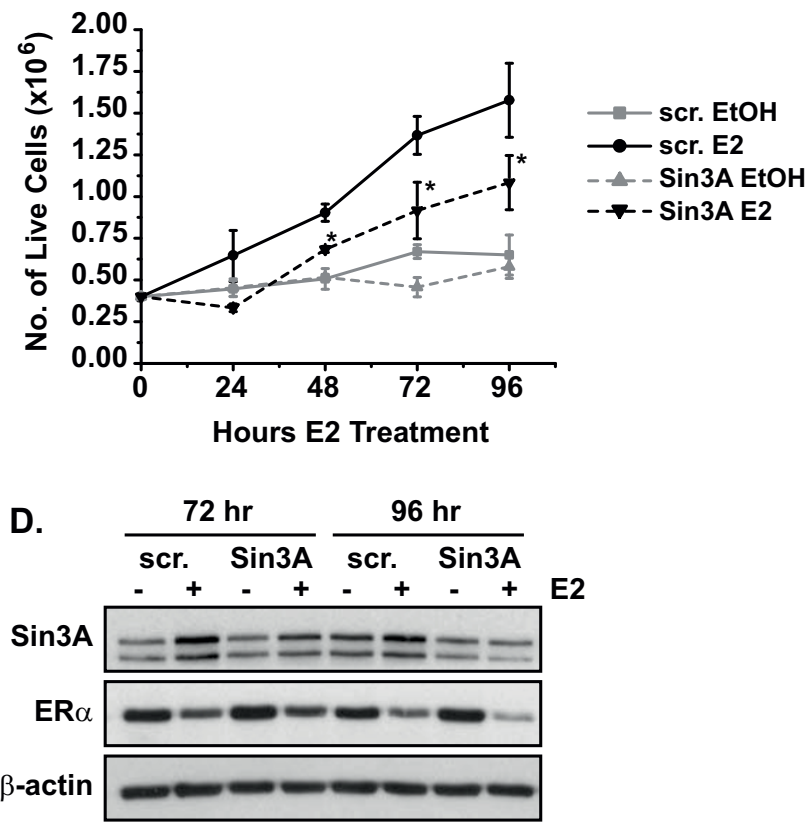

G. Hs578T
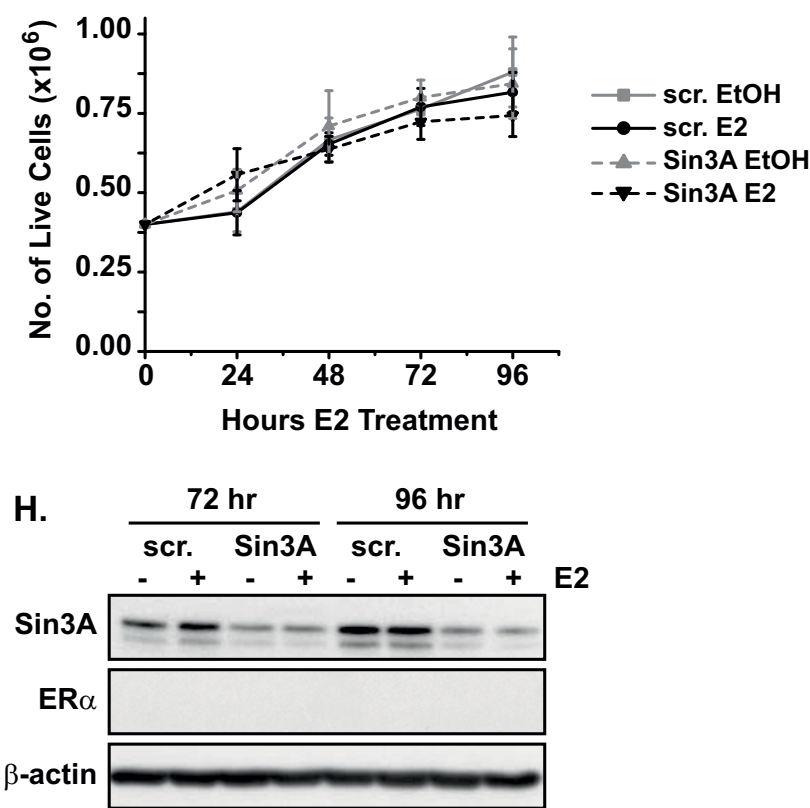

Figure $4 \operatorname{Sin} 3 \mathrm{~A}$ is required for maximum growth of ER $\alpha$-positive, but not ER $\alpha$-negative, breast cancer cells. ER $\alpha$-positive (A, B) MCF7 and $(\mathbf{C}, \mathbf{D})$ T47D cells, or ER $\alpha$-negative (E, F) MDA-MB-231 and (G, H) Hs578T cells, were transfected with either scrambled (scr.) negative control or Sin3A siRNA. Cells were then treated with vehicle ethanol $(\mathrm{EtOH})$ or $10 \mathrm{nM}$ estrogen (E2). Cells from each group were harvested at daily intervals, and the number of live cells was determined by trypan blue exclusion and counting. Error bars show the standard error of the mean of three independent experiments. Lysates from 72 and 96 hour time points were subjected to western blot analysis to confirm efficient knockdown of $\operatorname{Sin} 3 A(B, D, F, H)$. Blots were reprobed for ER $\alpha$ and the loading control, $\beta$-actin. To determine significance of loss of Sin3A on estrogen-induced growth of cells in (A) and (C), student's $t$ tests were performed comparing scrambled and Sin3A siRNA samples at each time point, ${ }^{*} p<0.05$. 
but no cell growth was observed in the scrambled ethanol group, consistent with the fact that this is an estrogendependent cell line (Figure 4A). Notably, a significant decrease in estrogen-induced growth of MCF7 cells was exhibited by those transfected with Sin3A siRNA. MCF7 cells transfected with the Sin3A siRNA but treated with ethanol also tended to have lower cell numbers than the corresponding scrambled control, but data were not statistically significant. T47D cells, another ER $\alpha$-positive cell line, also exhibited significant attenuation of estrogeninduced growth in the presence of Sin3A siRNA (Figure $4 \mathrm{C})$. The growth defect was not as dramatic as that observed in MCF7 cells. It is of note that knockdown of Sin3A protein, shown by Western blot analysis in Figure 4D, was also less efficient in the T47D cells. In contrast to the ER $\alpha$-positive cell lines, ER $\alpha$-negative MDA-MB-231 and Hs578T cells grew at the same rate in the presence and absence of Sin3A siRNA or estrogen (Figure 4E and $4 G$ ). These data provide evidence that $\operatorname{Sin} 3 \mathrm{~A}$ is required for maximum growth of ER $\alpha$-positive MCF7 and T47D cells but not ER $\alpha$-negative MDA-MB-231 and Hs578T cells.

Western blot analyses in Figure 4B, D, F, and 4H confirmed that Sin3A was decreased and could not account for different dependencies on Sin3A for growth in ER $\alpha$ positive versus $E R \alpha$-negative cell lines. Interestingly, western blot analysis revealed a robust estrogen-induced increase in Sin3A protein levels in control transfected MCF7 cells at both 72 and 96 hours (Figure 4B). This increase was also observed in T47D cells, albeit to a lesser extent (Figure 4D). Data from earlier time points of four hours estrogen treatment did not show this increase in Sin3A, suggesting that it is a long-term or secondary response (Figure $1 \mathrm{~A}$ and $5 \mathrm{C}$ ). Further estrogen time course western blot experiments showed that Sin3A protein levels increased by 24 hours of estrogen treatment in MCF7 cells, and this was sustained at a similar level out to 96 hours (Additional File 1A). The increase in Sin3A protein was independent of effects on transcription of SIN3A mRNA (Additional File 1B). Estrogen treatment did not affect the levels of SIN3A mRNA at any time point, but estrogen did decrease the levels of ESR1 as a positive control for estrogen responsiveness (Additional File 1C) [9,30]. The observation that high levels of Sin3A protein are maintained with long-term estrogen treatment further supports its role in promoting survival of ER $\alpha$-positive cells.

\section{Sin3A differentially represses expression of key apoptotic genes in ER $\alpha$-positive versus ER $\alpha$-negative breast cancer cells}

Data in Figure 3 suggested that Sin3A affected growth of ER $\alpha$-positive cells by regulation of apoptosis and not cellular proliferation. To provide mechanistic insight
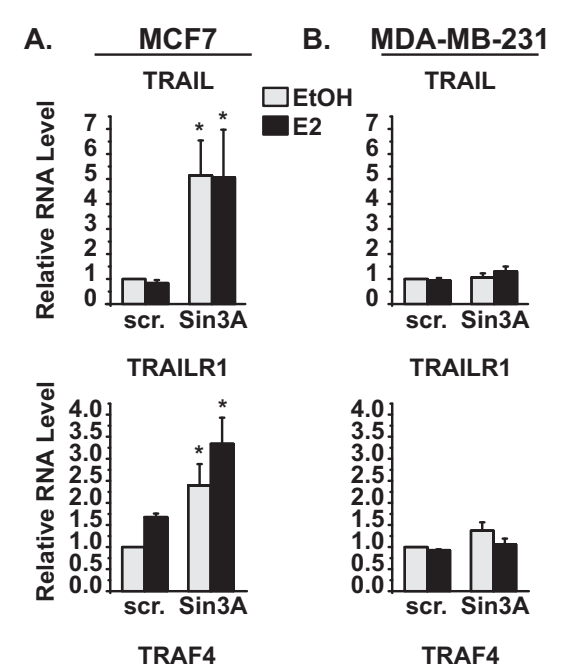

TRAILR1
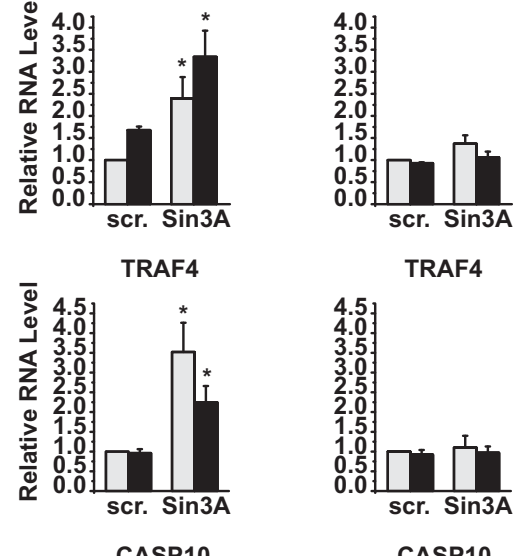

TRAF4

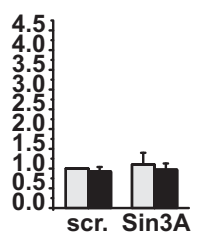

CASP10
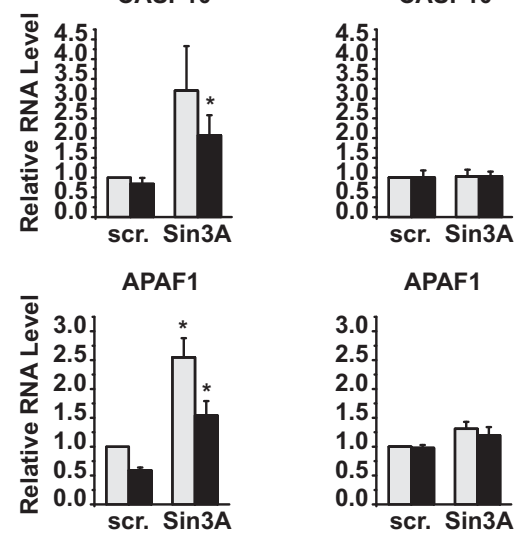

APAF1
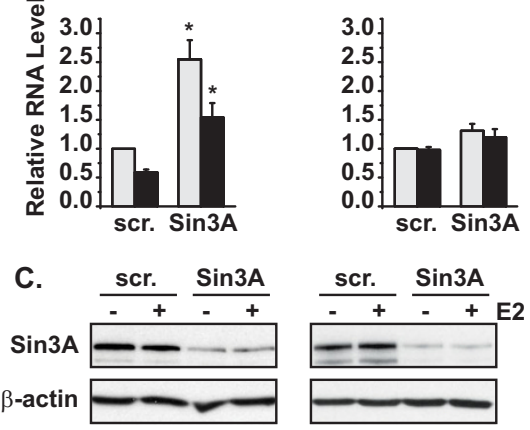

Figure 5 Loss of Sin3A increases expression of apoptotic genes differentially in ER $\alpha$-positive and ER $\alpha$-negative cell lines. (A) MCF7 or (B) MDA-MB-231 cells were transfected with scrambled (scr.) negative control or $\operatorname{Sin} 3 \mathrm{~A}$ siRNA, followed by treatment with vehicle control ethanol (EtOH) or $10 \mathrm{nM}$ estrogen (E2) for four hours. QRT-PCR was performed for the indicated apoptotic gene, with ribosomal protein PO serving as the housekeeping normalization gene. RNA levels were calculated relative to the scrambled ethanol sample. Data are from a minimum of three independent experiments with error bars showing the standard error of the mean. Student's $t$ tests were performed comparing corresponding scrambled and Sin3A siRNA samples, ${ }^{*} p<0.05$. (C) Knockdown of Sin $3 A$ protein was also confirmed by western blot analysis in each cell line. The blot was reprobed with $\beta$-actin for the loading control. 
into the increase in apoptosis, qRT-PCR analysis was performed to identify Sin3A-regulated apoptotic genes. MCF7 cells were transfected with scrambled or Sin3A siRNA and treated with ethanol or estrogen, as in Figure 1. Several apoptotic genes were analyzed, including those involved in both the extrinsic death receptor and the intrinsic mitochondrial stress signaling pathways [31]. Genes involved in the extrinsic death receptor pathway that were significantly increased upon loss of Sin3A in MCF7 cells were the apoptotic-inducing ligand TRAIL (also known as TNFSF1O or $A P O 2 L$ ), one of its receptors TRAILR1 (also termed TNFRSF10A, APO2, or DR4), mediators TRAF4 and $T R A D D$, and CASP1O (Figure 5A and Additional File 2A). Other genes implicated in extrinsic death signaling that were tested but not significantly altered by Sin3A knockdown were TNF ligand, death receptors TNFRSF25 (also called $A P O 3$ or $D R 3$ ) and $F A S$, and the $F A D D$ mediator (data not shown). Three genes involved in the intrinsic mitochondrial stress signaling apoptotic pathway were also significantly increased with loss of Sin3A in MCF7 cells $A P A F 1, B N I P 3 L$, and CASP9 (Figure 5A and Additional File 2A). Notably, CASP9 was repressed by estrogen treatment, and this repression was reversed in the presence of Sin3A siRNA (Additional File 2A). Expression of another key mitochondrial stress gene, $B C L 2$, was not responsive to Sin3A (data not shown).

Regulation of apoptotic genes was also determined in ER-negative MDA-MB-231 cells. qRT-PCR analysis was performed on genes from cells transfected with Sin3A siRNA and found that the majority of apoptotic genes were repressed by Sin3A in MCF7 cells, but not MDAMB-231 cells (Figure 5B and Additional File 2B). Specifically, TRAIL, TRAILR1, TRAF4, CASP10, and APAF1 were not significantly altered by loss of Sin3A in MDA-MB-231 cells (Figure 5B). Three genes, TRADD, BNIP3L, and $C A S P$, were significantly increased in MDA-MB-231 cells transfected with Sin3A siRNA, but to a lower level than MCF7 cells (Additional File 2B). Western blot analysis in Figure $5 \mathrm{C}$ again confirmed that Sin3A levels were efficiently decreased in both cell lines and could not be the reason for the disparate gene regulation. Together, these data show that Sin3A differentially regulates the expression of apoptotic genes in ER $\alpha$-positive MCF7 cells and $E R \alpha$-negative MDA-MB-231 cells, which may selectively influence the growth and survival of the ER $\alpha$-positive subtype of breast cancer.

\section{Discussion}

Previous studies had suggested a role for Sin3A in growth of normal and neoplastic cells, but the function of Sin3A in breast cancer had not been fully explored $[10,11]$. Prior research from our lab identified Sin3A as a regulator of ER $\alpha$ gene, ESR1, expression and found an estrogen-responsive interaction between $\mathrm{ER} \alpha$ and $\operatorname{Sin} 3 \mathrm{~A}$
[9]. This led us to further determine Sin3A regulation of gene expression and growth in breast cancer cells. We find that Sin3A regulates a subset of genes in ER $\alpha$ positive MCF7 cells through both HDAC1/2-dependent and -independent activities. Maximum growth and survival of ER $\alpha$-positive MCF7 and T47D cells requires expression of Sin3A. Interestingly, we also find that estrogen causes an increase in Sin3A protein levels in $E R \alpha$-positive cells, suggesting the involvement of Sin $3 \mathrm{~A}$ in a feedback circuit regulating estrogen-dependent growth of breast cancer cells. Further, Sin3A represses important apoptotic genes in ER $\alpha$-positive cell lines, consistent with our finding that decreased Sin3A levels leads to cellular apoptosis.

This study identifies the transcriptional repressor, Sin3A, as a necessary survival factor in ER $\alpha$-positive breast cancer cells. Our data further support the idea that Sin3A promotes growth and survival of cells proposed in previous studies $[10,11]$. Together, these results raise the intriguing possibility that gene repression is as important of a determinant for cell growth as gene activation, as $\operatorname{Sin} 3 \mathrm{~A}$ primarily functions as a repressor. Other chromatin modifying repressor proteins, including the MTA components of the Mi-2/NuRD complex and EZH2, are also associated with breast cancer growth and progression [32-35]. Our identification of Sin3A as a prosurvival factor is further interesting in that it highlights the importance of estrogen-mediated survival of breast cancer cells. Sin3A knockdown increased apoptosis but had no effect on the cell cycle (Figure 3). Estrogen is commonly viewed as a mitogenic agent that increases growth of breast cancer cells through cell cycle progression, but our data support the notion that estrogen-mediated repression of apoptosis also has a large impact on overall growth of cells $[29,36]$.

Clinical trials for HDAC inhibitors in breast cancer treatment, such as vorinostat, are still in early phases and often involve patients with advanced disease [37-40]. These studies have seen only partial efficacy that often increases when in combination with other agents, such as chemotherapy, and there are often issues of toxicity [37-40]. Our data suggest that developing therapeutic agents to target the scaffolding component of HDAC-complexes, such as Sin3A, may be of value, particularly because Sin3A affected only a subset of genes, but its loss still caused cell death. An agent that could disrupt Sin3A would target both its HDACdependent and -independent activities, possibly expanding the efficacy beyond that of HDAC inhibitors. Other reports support the finding that $\operatorname{Sin} 3 \mathrm{~A}$ has both HDAC1/2-dependent and -independent capabilities. For example, in stem cells, Sin3A is the key member of the Sin3 complex involved in the regulation of NANOG gene expression, not HDAC1/2 [41]. Several studies 
have also shown that Sin3A can interact with histone methylases (Smyd2, Set1/Ash2, and ESET), DNA methylation proteins $(\mathrm{MeCP} 2)$, chromatin remodeling enzymes (ISWI, Brg1, hBrm, and BAF155), and O-linked Nacetylglucosamine transferase (OGT), demonstrating that Sin3A has the potential to serve as an integrator of broad transcriptional and epigenetic changes in cells [20,23-28]. Furthermore, in vitro transcription reactions on reconstituted nucleosomal templates find that addition of the HDAC inhibitor, trichostatin A (TSA), abolishes Sin3A-mediated repression of an acetylated histone $\mathrm{H} 3$ template, but not acetylated histone $\mathrm{H} 4$ template [42]. This in vitro experiment shows that $\operatorname{Sin} 3 \mathrm{~A}$, even in the absence of other repressor molecules and enzymatic proteins, possesses some intrinsic HDAC1/2independent capabilities.

Our data show that loss of Sin3A increases apoptosis of ER $\alpha$-positive MCF7 cells (Figure 3). Upon further mechanistic experiments, we find that several genes with known roles in apoptosis are increased with Sin3A knockdown. This suggests that Sin3A normally represses their expression in MCF7 cells to aide in preventing apoptosis, and subsequently, promote cell growth. The apoptotic gene targets we identified fall into both the extrinsic death receptor and intrinsic mitochondrial apoptotic signaling pathways [31]. Interestingly, we find that $\operatorname{Sin} 3 \mathrm{~A}$ regulates genes involved in all steps of the extrinsic pathway in MCF7 cells - ligands, death receptors, adaptors, and caspases (Figure 5A and Additional File 2A) [43]. Specifically, levels of the TRAIL ligand, and its receptor, TRAILR1, are increased in MCF7 cells with Sin3A siRNA. TRAIL is a member of the tumor necrosis factor (TNF) superfamily of cytokines which can induce apoptosis by binding to extracellular domains of one of its receptors, which includes TRAILR1, a member of the TNF receptor superfamily [44-46]. Death receptors further use interactions with intracellular adaptor proteins to mediate signals from the extracellular environment, and loss of Sin3A increased levels of both TRADD and TRAF4 adaptors [47,48]. Lastly, we identify CASP10 as a Sin3A-responsive gene. In addition to caspase 8 , caspase 10 has been shown to act as an initiator caspase in the death receptor signaling pathway, which can lead to activation of downstream executioner caspases to cause apoptosis [49].

Three genes connected to the intrinsic mitochondrial apoptotic-inducing pathway are also regulated by $\operatorname{Sin} 3 \mathrm{~A}$ in MCF7 cells - APAF1, CASP9, and BNIP3L (Figure 5A and Additional File 2A). The involvement and connection of Apaf-1 and caspase 9 in stress-induced apoptosis has been studied in great detail. Briefly, cellular stress stimulates release of cytochrome $\mathrm{c}$ from the mitochondria where it can then bind to Apaf-1, inducing conformational changes, ATP hydrolysis, and multimerization of Apaf-1 [50]. The complex, referred to as the "apoptosome", then recruits and activates procaspase 9, and active caspase 9 can cleave executioner caspases to cause apoptosis [51,52]. Finally, BNIP3L (also known as $N I X)$ is a proapoptotic member of the Bcl-2 family of proteins that function upstream of the apoptosome to regulate the release of cytochrome $\mathrm{c}$ from the mitochondria $[53,54]$. Our findings that Sin3A regulates key genes from both the death receptor and mitochondrial stress apoptotic-inducing pathways emphasize the importance of this transcriptional repressor.

Our data find that Sin3A differentially regulates the expression of the apoptotic genes discussed above in ER $\alpha$-positive (MCF7) and ER $\alpha$-negative (MDA-MB-231) cell lines. TRAIL, TRAILR1, TRAF4, CASP10, and $A P A F 1$ increase upon Sin3A knockdown in MCF7, but not MDA-MB-231, breast cancer cells (Figure 5). Three genes, TRADD, BNIP3L, and CASP9, increase in both cell lines with loss of Sin3A, demonstrating that Sin3A possesses some overlapping gene regulation between breast cancer cell lines, as may be expected (Additional File 2). However, it is of note that the increase seen in these three genes upon Sin3A knockdown is greater in the MCF7 cells. Differences in apoptotic gene regulation by $\operatorname{Sin} 3 \mathrm{~A}$ in ER $\alpha$-subtypes can mechanistically explain the discrepancies seen in effects of Sin3A on cell growth. Induction of apoptotic genes in the ER $\alpha$-positive MCF7, and not ER $\alpha$-negative MDA-MB-231 cells, could lead to increases in apoptosis and a resulting decrease in cell growth, as we observe. Furthermore, Sin3A protein itself is increased by estrogen in the ER $\alpha-$ positive breast cancer cell lines, discussed below.

To our knowledge, this is one of the first studies to identify a regulator of Sin3A levels - estrogen. Most studies concerning Sin3A have focused on its ability to regulate expression of other genes, and little knowledge exists about how levels of Sin3A itself are modulated. Another study has shown that Sin3A can be sumoylated by TOPORS, but other modulators of Sin3A are virtually unknown [55]. We observe an estrogen-induced increase in Sin3A protein levels that occurs independent of effects on Sin3A mRNA, demonstrating that regulation of Sin3A occurs via nongenomic actions (Additional File 1). This suggests that differences in Sin3A expression would not be found in microarray studies, possibly explaining why the role of Sin3A in breast cancer has not been appreciated until now. The mechanism by which estrogen treatment increases Sin3A protein levels is likely via a secondary effect since elevated levels are not seen before 24 hours (Figure $1 \mathrm{~A}$ and $5 \mathrm{C}$ ). Different $\mathrm{ER} \alpha$-positive cell types also seem to have a greater dependency on Sin3A levels for survival and growth than 
others. For example, we find a greater induction of $\operatorname{Sin} 3 \mathrm{~A}$ protein in MCF7 than T47D cells, and subsequently, a greater effect of Sin3A on growth of MCF7 cells (Figure $4)$.

While this manuscript was under revision, another group published that the Sin3 complex represses the $E R \alpha$ gene, ESR1, in ER $\alpha$-negative breast cancer cell lines [56]. Consistent with this finding, we showed Sin3A regulation of estrogen-induced repression of ESR1 in MCF7 cells [9]. However, unlike the other publication, we did not observe reexpression of either ESR1 mRNA (data not shown) or ER $\alpha$ protein (Figure $4 \mathrm{~F}$ ) in MDA-MB-231 in our current studies. These discrepancies may be due to different experimental conditions and techniques. Importantly, the authors in [56] disrupted Sin3A and Sin3B function by using the Sin3 interaction domain (SID) of the MAD protein, while our experiments focused only on Sin3A. Additionally, the SID from MAD may participate in other protein interactions beyond the Sin 3 proteins. Together, these reports suggest that components besides $\operatorname{Sin} 3 \mathrm{~A}$ are necessary to mediate the repression of ESR1 in ER $\alpha$ negative cells.

Finally, our data show several converging points between Sin3A and the estrogen signaling pathway. As described above, estrogen increases protein levels of Sin3A, suggesting a feedback loop to control estrogendependent growth. Our previous report shows that Sin3A controls expression of the ER $\alpha$ gene itself, ESR1, and $\operatorname{Sin} 3 \mathrm{~A}$ can interact with ER $\alpha$ in ER $\alpha$-positive breast cancer cells [9]. We further show here that Sin3A controls expression of $N C O A 2$, a member of the p160 coactivator family involved in mediating ER $\alpha$ transcriptional activation (Figure 1D) [57]. The estrogen-induced activation of $P G R$, which encodes the progesterone receptor $(\mathrm{PR})$, also increases upon Sin3A knockdown (Figure 1D). PR status is often used as a marker of estrogen sensitivity and predictor of response to endocrine therapy in breast cancer [58,59]. Additionally, knockdown of Sin3A only prevents growth of ER $\alpha$-positive MCF7 and T47D cells, not ER $\alpha$-negative MDA-MB-231 and Hs578T cells, further supporting the notion that components intrinsic to the $E R \alpha$ signaling pathway are involved in mediating the ability of Sin $3 \mathrm{~A}$ to promote survival.

\section{Conclusions}

This is one of the first studies to analyze the role of the Sin3A transcriptional repressor protein in breast cancer. We find that Sin3A regulates the expression of several genes important in breast cancer and estrogen signaling, and these effects are mediated through both HDAC1/2dependent and -independent mechanisms of Sin3A. Our findings show that $\operatorname{Sin} 3 \mathrm{~A}$ is a prosurvival protein that promotes growth of ER $\alpha$-positive breast cancer cells by preventing apoptosis through repression of key proapoptotic genes. These findings suggest that Sin3A may be a new therapeutic target, and identification of an agent that could disrupt Sin3A may be effective in controlling survival of ER $\alpha$-positive tumors.

\section{Methods}

\section{Cell Culture and Hormone Treatments}

MCF7, MDA-MB-231, and Hs578T cells were maintained at $37^{\circ} \mathrm{C}$ and $10 \% \mathrm{CO}_{2}$ in Dulbecco's modified Eagle's medium (DMEM; Mediatech, Inc., Manassas, VA, USA) with phenol red and L-glutamine, supplemented with $10 \%$ fetal bovine serum (FBS; Biowest, Miami, FL, USA), $100 \mathrm{units} / \mathrm{ml}$ penicillin, and $100 \mu \mathrm{g} / \mathrm{ml}$ streptomycin (GIBCO/Invitrogen, Carlsbad, CA, USA). T47D cells were maintained at $37^{\circ} \mathrm{C}$ and $5 \% \mathrm{CO}_{2}$ in RPMI 1640 medium with phenol red and L-glutamine (GIBCO), supplemented with $10 \%$ FBS, penicillin, and streptomycin as above. For hormone treatments, all cell lines were incubated at $37^{\circ} \mathrm{C}$ and $5 \% \mathrm{CO}_{2}$ for at least three days in the media described above but without phenol red and containing six-times charcoal dextran stripped FBS. 17$\beta$-estradiol (estrogen, E2; Steraloids, Inc., Newport, RI, USA) was added to a final concentration of $10 \mathrm{nM}$ in all experiments for the length of time indicated in the figures. Ethanol $(\mathrm{EtOH})$ vehicle control was $0.1 \%$ in all samples.

\section{Transfection of siRNA}

One day prior to transfection, cells were plated in $10 \mathrm{~cm}$ plates at a density of $2 \times 10^{6}$ cells in antibiotic free media. 800 pmol of siRNA was diluted in Lipofectamine reagent (Invitrogen) and Opti-MEM (GIBCO) and added to appropriate plates for five hours. Three days later, cells were transfected with siRNA again as above in order to achieve maximum silencing. siRNA duplexes for Sin3A, HDAC1, HDAC2, and a scrambled negative control were predesigned and purchased from Sigma (Saint Louis, MO, USA).

\section{RNA Isolation and Quantitative RT-PCR}

RNA isolation and quantitative reverse transcriptase real-time PCR (qRT-PCR) were carried out as previously detailed [9]. Primer sequences are available upon request. Ribosomal protein P0 mRNA was used as the internal control. Relative mRNA levels were calculated using the $\Delta \Delta C t$ method [60]. For initial screening of candidate Sin3A-regulated genes, two complimentary trial $\mathrm{RT}^{2}$ Profiler Human Breast Cancer and Estrogen Receptor Signaling PCR arrays were used (SABiosciences now a Qiagen company, Frederick, MD, USA). 


\section{Western Blot Analysis}

Western blot analysis was carried out as previously described [61]. The primary antibodies used in this study were Sin3A (K-20, sc-994, Santa Cruz Biotechnology, Santa Cruz, CA, USA), ER $\alpha$ (VP-E613, Vector Laboratories, Burlingame, CA, USA), HDAC1 (H-11, sc8410, Santa Cruz), HDAC2 (C-8, sc-9959, Santa Cruz), $\beta$-actin (A5441, Sigma), and $\alpha$-tubulin (DM1A, CP06, Calbiochem, San Diego, CA, USA).

\section{Cell Growth Assays}

Cells were transfected with scrambled or Sin3A siRNA as detailed above, changing the media to phenol-red free media the day before the second transfection. The day after the second transfection, cells were harvested and plated in 6-well plates at a density of $4 \times 10^{5}$ live cells, as determined by trypan blue exclusion and counting on a hemacytometer. Cells were then treated with either $10 \mathrm{nM}$ $\mathrm{E} 2$ or EtOH. At 24 hour intervals, cells were harvested and resuspended in media. The number of live cells at each time point was determined by hemacytometer counting and trypan blue exclusion, taking the average of two counts for each sample in each experiment.

\section{Flow Cytometry for Cell Cycle and Apoptosis Analysis}

Knockdown of Sin3A and hormone treatments were performed as described above. 72 and 96 hours posttreatment, media and cells were harvested and diluted to $1 \times 10^{5}$ cells in $1 \mathrm{ml}$ of media. Hoescht (Invitrogen) was added at $10 \mu \mathrm{g} / \mathrm{ml}$ to the cells, and samples were incubated for 30 minutes at $37^{\circ} \mathrm{C}$. Cells were spun down and resuspended in $100 \mu \mathrm{l}$ of annexin binding buffer (10 $\mathrm{mM}$ HEPES, $140 \mathrm{mM} \mathrm{NaCl}$, and $2.5 \mathrm{mM} \mathrm{CaCl}_{2}, \mathrm{pH} 7.4$ ) containing Hoescht. $5 \mu \mathrm{l}$ of the annexin V-Alexa Fluor 647 conjugate (Invitrogen) was added to the cell suspension and incubated for 15 minutes at room temperature. After the incubation, an additional $400 \mu \mathrm{l}$ of annexin binding buffer was added, followed by propidium iodide (Sigma) to a concentration of $5 \mu \mathrm{g} / \mathrm{ml}$. Dye intensities of 10,000 events were measured on the LSRII machine from BD Biosciences (San Jose, CA, USA) equipped with a UV laser. Apoptosis levels were analyzed using FlowJo software (Tree Star, Inc., Ashland, OR, USA), and cell cycle data were analyzed using ModFit software (Verity Software House, Topsham, ME, USA).

\section{Statistical Analysis}

Error bars in all figures are the standard error of the mean of a minimum of three independent experiments. Statistics were performed using OrginLab (OrginLab Corp., Northampton, MA, USA), with the exact test described in the corresponding figure legend. Data were considered significant if $p<0.05$ and are indicated in the figures by asterisks.

\section{Additional material}

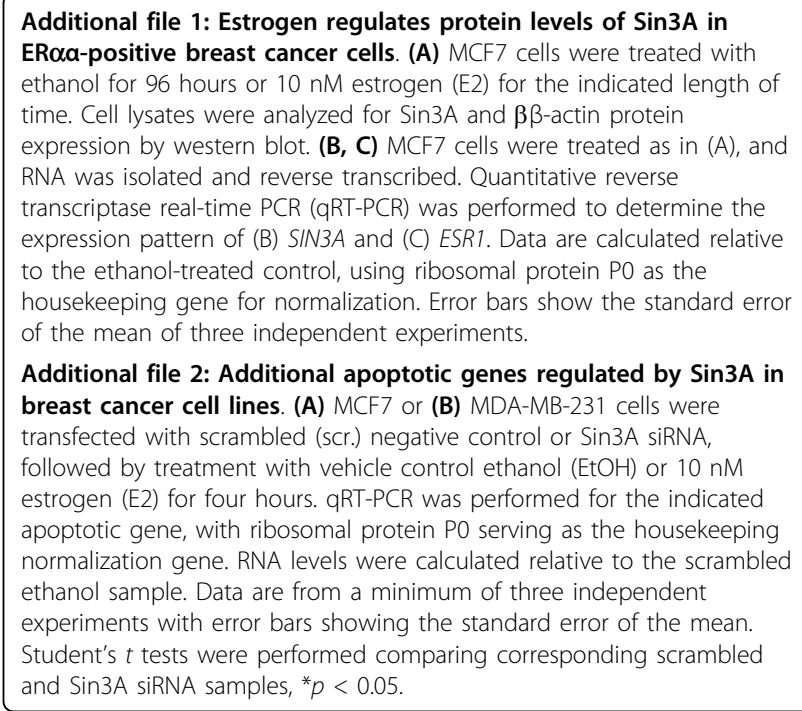

Acknowledgements

We would like to thank members of the Alarid laboratory, particularly Natalia Solodin for her excellent technical assistance. We also acknowledge the University of Wisconsin flow cytometry facility for assistance with flow experiments, particularly Dr. Erik Puffer. We also thank Dr. Wei Xu's lab for the Hs578T cell line. This work was supported by U.S. Department of Defense Breast Cancer Research Program Grant W81XWH-06-1-0729 (S.J.E.).

\section{Authors' contributions}

SE designed and performed experiments, analyzed data, and wrote the manuscript. EA assisted with experimental design, data analysis, and writing of the manuscript. All authors read and approved the final manuscript.

\section{Competing interests}

The authors declare that they have no competing interests.

Received: 23 March 2010 Accepted: 29 September 2010 Published: 29 September 2010

\section{References}

1. Paik S, Shak S, Tang G, Kim C, Baker J, Cronin M, Baehner FL, Walker MG, Watson D, Park T, Hiller W, Fisher ER, Wickerham DL, Bryant J, Wolmark N: A multigene assay to predict recurrence of tamoxifen-treated, nodenegative breast cancer. N Engl J Med 2004, 351:2817-2826.

2. Perou CM, Sorlie T, Eisen MB, van de Rijn M, Jeffrey SS, Rees CA, Pollack JR, Ross DT, Johnsen $H$, Akslen LA, Fluge O, Pergamenschikov A, Williams C, Zhu SX, Lonning PE, Borresen-Dale AL, Brown PO, Botstein D: Molecular portraits of human breast tumours. Nature 2000, 406:747-752.

3. van't Veer $L J$, Dai $H$, van de Vijver MJ, He YD, Hart AAM, Mao M, Peterse HL, van der Kooy K, Marton MJ, Witteveen AT, Schreiber GJ, Kerkhoven RM, Roberts C, Linsley PS, Bernards R, Friend SH: Gene expression profiling predicts clinical outcome of breast cancer. Nature 2002, 415: 530-536.

4. Macgregor Jl, Jordan VC: Basic guide to the mechanisms of antiestrogen action. Pharmacol Rev 1998, 50:151-196.

5. Carroll JS, Meyer CA, Song J, Li W, Geistlinger TR, Eeckhoute J, Brodsky AS, Keeton EK, Fertuck KC, Hall GF, Wang Q, Bekiranov S, Sementchenko V, Fox EA, Silver PA, Gingeras TR, Liu XS, Brown M: Genome-wide analysis of estrogen receptor binding sites. Nat Genet 2006, 38:1289-1297.

6. Frasor J, Danes JM, Komm B, Chang KC, Lyttle CR, Katzenellenbogen BS: Profiling of estrogen up- and down-regulated gene expression in human breast cancer cells: insights into gene networks and pathways 
underlying estrogenic control of proliferation and cell phenotype. Endocrinology 2003, 144:4562-4574.

7. Kininis M, Chen BS, Diehl AG, Isaacs GD, Zhang T, Siepel AC, Clark AG, Kraus WL: Genomic analyses of transcription factor binding, histone acetylation, and gene expression reveal mechanistically distinct classes of estrogen-regulated promoters. Mol Cell Biol 2007, 27:5090-5104.

8. Lin CY, Vega VB, Thomsen JS, Zhang T, Kong SL, Xie M, Chiu KP, Lipovich L, Barnett DH, Stossi F, Yeo A, George J, Kuznetsov VA, Lee YK, Charn TH, Palanisamy N, Miller LD, Cheung E, Katzenellenbogen BS, Ruan $Y$, Bourque G, Wei CL, Liu ET: Whole-genome cartography of estrogen receptor alpha binding sites. PLoS Genet 2007, 3:e87.

9. Ellison-Zelski SJ, Solodin NM, Alarid ET: Repression of ESR1 through actions of estrogen receptor alpha and $\operatorname{Sin} 3 \mathrm{~A}$ at the proximal promoter. Mol Cell Biol 2009, 29:4949-4958.

10. Cowley SM, Iritani BM, Mendrysa SM, Xu T, Cheng PF, Yada J, Liggitt HD, Eisenman RN: The mSin3A chromatin-modifying complex is essential for embryogenesis and T-cell development. Mol Cell Biol 2005, 25:6990-7004.

11. Dannenberg JH, David G, Zhong S, van der Torre J, Wong WH, Depinho RA: $\mathrm{mSin} 3 \mathrm{~A}$ corepressor regulates diverse transcriptional networks governing normal and neoplastic growth and survival. Genes Dev 2005, 19:1581-1595.

12. Suzuki H, Ouchida M, Yamamoto H, Yano M, Toyooka S, Aoe M, Shimizu N, Date $H$, Shimizu K: Decreased expression of the SIN3A gene, a candidate tumor suppressor located at the prevalent allelic loss region $15 q 23$ in non-small cell lung cancer. Lung Cancer 2008, 59:24-31.

13. Nasmyth K, Stillman D, Kipling D: Both positive and negative regulators of HO transcription are required for mother-cell-specific mating-type switching in yeast. Cell 1987, 48:579-587.

14. Sternberg PW, Stern MJ, Clark I, Herskowitz I: Activation of the yeast HO gene by release from multiple negative controls. Cell 1987, 48:567-577.

15. Hassig CA, Fleischer TC, Billin AN, Schreiber SL, Ayer DE: Histone deacetylase activity is required for full transcriptional repression by mSin3A. Cell 1997, 89:341-347.

16. Zhang $Y$, Iratni $R$, Erdjument-Bromage $H$, Tempst P, Reinberg D: Histone deacetylases and SAP18, a novel polypeptide, are components of a human Sin3 complex. Cell 1997, 89:357-364.

17. Silverstein RA, Ekwall K: Sin3: a flexible regulator of global gene expression and genome stability. Curr Genet 2005, 47:1-17.

18. Ayer DE, Lawrence QA, Eisenman RN: Mad-Max transcriptional repression is mediated by ternary complex formation with mammalian homologs of yeast repressor Sin3. Cell 1995, 80:767-776.

19. Murphy M, Ahn J, Walker KK, Hoffman WH, Evans RM, Levine AJ, George DL: Transcriptional repression by wild-type p53 utilizes histone deacetylases, mediated by interaction with mSin3a. Genes Dev 1999, 13:2490-2501.

20. Nan X, Ng HH, Johnson CA, Laherty CD, Turner BM, Eisenman RN, Bird A: Transcriptional repression by the methyl-CpG-binding protein MeCP2 involves a histone deacetylase complex. Nature 1998, 393:386-389.

21. Roopra A, Sharling L, Wood IC, Briggs T, Bachfischer U, Paquette AJ, Buckley NJ: Transcriptional repression by neuron-restrictive silencer factor is mediated via the Sin3-histone deacetylase complex. Mol Cell Biol 2000, 20:2147-2157.

22. Lutz M, Burke LJ, Barreto G, Goeman F, Greb H, Arnold R, Schultheiss H, Brehm A, Kouzarides T, Lobanenkov V, Renkawitz R: Transcriptional repression by the insulator protein CTCF involves histone deacetylases. Nucleic Acids Res 2000, 28:1707-1713.

23. Brown MA, Sims RJ, Gottlieb PD, Tucker PW: Identification and characterization of Smyd2: a split SET/MYND domain-containing histone H3 lysine 36-specific methyltransferase that interacts with the Sin3 histone deacetylase complex. Mol Cancer 2006, 5:26.

24. Burgio G, La Rocca G, Sala A, Arancio W, Di Gesu D, Collesano M, Sperling AS, Armstrong JA, van Heeringen SJ, Logie C, Tamkun JW, Corona DF: Genetic identification of a network of factors that functionally interact with the nucleosome remodeling ATPase ISWI. PLOS Genet 2008, 4:e1000089.

25. Wysocka J, Myers MP, Laherty CD, Eisenman RN, Herr W: Human Sin3 deacetylase and trithorax-related Set1/Ash2 histone H3-K4 methyltransferase are tethered together selectively by the cellproliferation factor HCF-1. Genes Dev 2003, 17:896-911.

26. Yang L, Mei Q, Zielinska-Kwiatkowska A, Matsui Y, Blackburn ML, Benedetti D, Krumm AA, Taborsky GJ, Chansky HA: An ERG (ets-related gene)-associated histone methyltransferase interacts with histone deacetylases $1 / 2$ and transcription co-repressors $\mathrm{mSin} 3 \mathrm{~A} / \mathrm{B}$. Biochem $J$ 2003, 369:651-657.

27. Yang $X$, Zhang F, Kudlow JE: Recruitment of O-GlcNAc transferase to promoters by corepressor mSin3A: coupling protein O-GIcNAcylation to transcriptional repression. Cell 2002, 110:69-80.

28. Sif S, Saurin AJ, Imbalzano AN, Kingston RE: Purification and characterization of mSin3A-containing Brg1 and $\mathrm{hBrm}$ chromatin remodeling complexes. Genes Dev 2001, 15:603-618.

29. Prall OW, Rogan EM, Sutherland RL: Estrogen regulation of cell cycle progression in breast cancer cells. J Steroid Biochem Mol Biol 1998, 65:169-174.

30. Saceda M, Lippman ME, Chambon P, Lindsey RL, Ponglikitmongkol M, Puente M, Martin MB: Regulation of the estrogen receptor in MCF-7 cells by estradiol. Mol Endocrinol 1988, 2:1157-1162.

31. Green DR: Apoptotic pathways: the roads to ruin. Cell 1998, 94:695-698.

32. Fujita N, Jaye DL, Kajita M, Geigerman C, Moreno CS, Wade PA: MTA3, a Mi-2/NuRD complex subunit, regulates an invasive growth pathway in breast cancer. Cell 2003, 113:207-219.

33. Zhang H, Stephens LC, Kumar R: Metastasis tumor antigen family proteins during breast cancer progression and metastasis in a reliable mouse model for human breast cancer. Clin Cancer Res 2006, 12:1479-1486.

34. Collett K, Eide GE, Arnes J, Stefansson IM, Eide J, Braaten A, Aas T, Otte AP, Akslen LA: Expression of enhancer of zeste homologue 2 is significantly associated with increased tumor cell proliferation and is a marker of aggressive breast cancer. Clin Cancer Res 2006, 12:1168-1174.

35. Kleer CG, Cao Q, Varambally S, Shen R, Ota I, Tomlins SA, Ghosh D, Sewalt RG, Otte AP, Hayes DF, Sabel MS, Livant D, Weiss SJ, Rubin MA, Chinnaiyan AM: EZH2 is a marker of aggressive breast cancer and promotes neoplastic transformation of breast epithelial cells. Proc Natl Acad Sci USA 2003, 100:11606-11611.

36. Gompel A, Somai S, Chaouat M, Kazem A, Kloosterboer HJ, Beusman I, Forgez $\mathrm{P}$, Mimoun M, Rostene W: Hormonal regulation of apoptosis in breast cells and tissues. Steroids 2000, 65:593-598.

37. Kristensen LS, Nielsen HM, Hansen LL: Epigenetics and cancer treatment. Eur J Pharmacol 2009, 625:131-142.

38. Wong ST: Emerging treatment combinations: integrating therapy into clinical practice. Am J Health Syst Pharm 2009, 66:S9-14.

39. Luu TH, Morgan RJ, Leong L, Lim D, McNamara M, Portnow J, Frankel P, Smith DD, Doroshow JH, Gandara DR, Aparicio A, Somlo G, Wong C: A phase II trial of vorinostat (suberoylanilide hydroxamic acid) in metastatic breast cancer: a California Cancer Consortium study. Clin Cancer Res 2008, 14:7138-7142.

40. Munster P, Marchion D, Bicaku E, Lacevic M, Kim J, Centeno B, Daud A, Neuger A, Minton S, Sullivan D: Clinical and biological effects of valproic acid as a histone deacetylase inhibitor on tumor and surrogate tissues: phase 1/II trial of valproic acid and epirubicin/FEC. Clin Cancer Res 2009, $15: 2488-2496$

41. Baltus GA, Kowalski MP, Tutter AV, Kadam S: A positive regulatory role for the mSin3A-HDAC complex in pluripotency through Nanog and Sox2. $J$ Biol Chem 2009, 284:6998-7006.

42. Vermeulen M, Walter W, Le Guezennec X, Kim J, Edayathumangalam RS, Lasonder E, Luger K, Roeder RG, Logie C, Berger SL, Stunnenberg HG: A feed-forward repression mechanism anchors the Sin3/histone deacetylase and N-CoR/SMRT corepressors on chromatin. Mol Cell Biol 2006, 26:5226-5236.

43. Ashkenazi A, Dixit VM: Death receptors: signaling and modulation. Science 1998, 281:1305-1308

44. Pan G, O'Rourke K, Chinnaiyan AM, Gentz R, Ebner R, Ni J, Dixit VM: The receptor for the cytotoxic ligand TRAIL. Science 1997, 276:111-113.

45. Pitti RM, Marsters SA, Ruppert S, Donahue CJ, Moore A, Ashkenazi A Induction of apoptosis by Apo-2 ligand, a new member of the tumor necrosis factor cytokine family. J Biol Chem 1996, 271:12687-12690.

46. MacFarlane M: TRAlL-induced signaling and apoptosis. Toxicol Lett 2003, 139:89-97.

47. Hsu H, Xiong J, Goeddel DV: The TNF receptor 1-associated protein TRADD signals cell death and NF-kappa B activation. Cell 1995, 81:495-504.

48. Sax JK, El-Deiry WS: Identification and characterization of the cytoplasmic protein TRAF4 as a p53-regulated proapoptotic gene. J Biol Chem 2003, 278:36435-36444. 
49. Wang J, Chun HJ, Wong W, Spencer DM, Lenardo MJ: Caspase-10 is an initiator caspase in death receptor signaling. Proc Natl Acad Sci USA 2001, 98:13884-13888.

50. Zou H, Henzel WJ, Liu X, Lutschg A, Wang X: Apaf-1, a human protein homologous to $C$. elegans CED-4, participates in cytochrome Cdependent activation of caspase-3. Cell 1997, 90:405-413.

51. Ledgerwood EC, Morison IM: Targeting the apoptosome for cancer therapy. Clin Cancer Res 2009, 15:420-424.

52. Li P, Nijhawan D, Budihardjo I, Srinivasula SM, Ahmad M, Alnemri ES, Wang X: Cytochrome $\mathrm{c}$ and dATP-dependent formation of Apaf-1/ caspase-9 complex initiates an apoptotic protease cascade. Cell 1997, 91:479-489.

53. Fei P, Wang W, Kim Sh, Wang S, Burns TF, Sax JK, Buzzai M, Dicker DT, McKenna WG, Bernhard EJ, El-Deiry WS: Bnip3L is induced by p53 under hypoxia, and its knockdown promotes tumor growth. Cancer Cell 2004, 6:597-609.

54. Chinnadurai G, Vijayalingam S, Gibson SB: BNIP3 subfamily BH3-only proteins: mitochondrial stress sensors in normal and pathological functions. Oncogene 2009, 27:S114-S127.

55. Pungaliya P, Kulkarni D, Park HJ, Marshall H, Zheng H, Lackland H, Saleem A, Rubin EH: TOPORS functions as a SUMO-1 E3 ligase for chromatinmodifying proteins. J Proteome Res 2007, 6:3918-3923.

56. Farias EF, Petrie K, Leibovitch B, Murtagh J, Chornet MB, Schenk T, Zelent A, Waxman S: Interference with $\operatorname{Sin} 3$ function induces epigenetic reprogramming and differentiation in breast cancer cells. Proc Natl Acad Sci USA 2010, 107:11811-11816.

57. Hong H, Kohli K, Trivedi A, Johnson DL, Stallcup MR: GRIP1, a novel mouse protein that serves as a transcriptional coactivator in yeast for the hormone binding domains of steroid receptors. Proc Natl Acad Sci USA 1996, 93:4948-4952.

58. Osborne CK, Yochmowitz MG, Knight WA, McGuire WL: The value of estrogen and progesterone receptors in the treatment of breast cancer. Cancer 1980, 46:2884-2888.

59. Ravdin PM, Green S, Dorr TM, McGuire WL, Fabian C, Pugh RP, Carter RD, Rivkin SE, Borst JR, Belt RJ: Prognostic significance of progesterone receptor levels in estrogen receptor-positive patients with metastatic breast cancer treated with tamoxifen: results of a prospective Southwest Oncology Group study. J Clin Oncol 1992, 10:1284-1291.

60. Livak KJ, Schmittgen TD: Analysis of relative gene expression data using real-time quantitative PCR and the 2(-Delta Delta C(T)) Method. Methods 2001, 25:402-408.

61. Valley CC, Solodin NM, Powers GL, Ellison SJ, Alarid ET: Temporal variation in estrogen receptor-alpha protein turnover in the presence of estrogen. $J$ Mol Endocrinol 2008, 40:23-34.

doi:10.1186/1476-4598-9-263

Cite this article as: Ellison-Zelski and Alarid: Maximum growth and survival of estrogen receptor-alpha positive breast cancer cells requires the Sin3A transcriptional repressor. Molecular Cancer 2010 9:263.

\section{Submit your next manuscript to BioMed Central and take full advantage of:}

- Convenient online submission

- Thorough peer review

- No space constraints or color figure charges

- Immediate publication on acceptance

- Inclusion in PubMed, CAS, Scopus and Google Scholar

- Research which is freely available for redistribution

Submit your manuscript at www.biomedcentral.com/submit
Biomed Central 